RESEARCH ARTICLE

\title{
Genetic Studies on Correlation and Path Analysis in Dolichos Bean (Lablab Purpureus L.) Genotypes
}

\section{Geetha $K$ * and Divya S}

Regional Research Station, Paiyur, Tamil Nadu Agricultural University, Krishnagiri district - 635112

\begin{abstract}
The present study was aimed to carry out correlation and path analysis in Dolichos Bean (Lablab Purpureus L.) Genotypes. The field experiment was carried out using twenty-six genotypes of field bean in Randomized Block Design with three replications. Biometrical observations were recorded on days to fifty percent flowering, days to maturity, plant height, number of branches/plant, number of pod/plant, grain yield (g) and green pod yield (g). Among the various polygenic characters, yield is a complex character and it depends on several yield attributing characters. Hence, the knowledge of association between yield and its component traits is needed, which forms the basis for selection. Partitioning of total correlation into direct and indirect effects by path coefficient analysis helps gain information on the relative status of the plant characters, making the selection more effective. At both phenotypic and genotypic levels, green pod yield recorded moderately significant and positive correlation with plant height and number of branches/plant and the traits viz., number of pod/plant and grain yield (g) exhibited an extremely significant and positive correlation with green pod yield. Days to maturity showed the first maximum positive direct effect (3.986) on green pod yield, followed by number of pod/plant (2.241) and number of branches/plant (0.143). Whereas the other characters viz., days to fifty percent flowering, plant height and grain yield recorded direct negative effect on green pod yield. The results indicated that the characters viz., days to maturity, number of branches/plant, number of pod/plant and green pod yield were the most desirable yield contributing characters. Their contribution to grain yield and green pod yield is in positive direction via direct effect. Hence, selection based on these characters would be rewarding for improving grain yield and green pod yield in Dolichos bean.
\end{abstract}

Keywords: Correlation; Path analysis ; Dolichos bean

\section{INTRODUCTION}

Dolichos bean (Lab-lab purpureus var. lignosus) is a leguminous vegetable mainly grown for green pods and dry seeds. This crop is also called as sem, hyacinth bean and field bean. It belongs to the family fabaceae with chromosome number $2 n=2 x=22$. It is a crop of ancient origin with food and fodder value. India is considered as origin and primary centre of diversity for dolichos bean based on historical evidence. This bean has been in cultivation for 3000 years (Magalingam et al., 2013). It is a perennial twining climber, but it is also cultivated as annual. It is maintained as an annual crop or on fences as perennial in home gardens. In some parts of India, it is grown as forage for livestock. Dolichos bean is cultivated in semi-arid and dry regions of Asia, Africa and America. With limited rainfall, the crop is grown in drylands. The crop grows well comparatively in cool-season during July - August. It initiates fruiting in winter and remains indeterminately in spring. Dolichos bean contributes to the rich source of protein in the preparations in India. It is a field crop mostly confined to a great extent in the regions of Andhra Pradesh, Tamil Nadu, Karnataka, Chhattisgarh and to some extent in parts of Bihar and Uttar Pradesh. In this, Karnataka alone contributes to $90 \%$ of the area and production. It can be grown either as a single crop or intercrop with finger millet or pearl millet.

Dolichos bean is photo-sensitive crop and requires short days for flowering. Dolichos bean has multiple benefits, its green pods and seeds are used as vegetable, and dry seeds are stored and used as pulse throughout the year. The green pods 
are used for consumption after cooking and have higher nutritive value of protein $(3.8 \mathrm{~g})$, fat $(0.7$ g), minerals (0.9 g), magnesium (34 mg), calcium (210 mg), phosphorus (68 mg), sodium (55.4 mg), iron (1.7 mg), potassium (74 mg) and sulphur (40 $\mathrm{mg})$. Moreover, immature pods are rich in dietary fiber, low in carbohydrates, and lipids. Beside these, Dolichos bean has medicinal properties of fighting against breast cancer due to the presence of kievitone (Hoffman, 1995). In addition, tyrosinase present in the Dolichos bean greater potential to treat hypertension in humans. Dolichos bean is referred as 'orphan legume crop' because of their underutilization and lack of global cultivation, yet they have high nutritional properties, heat and drought tolerant capability.

Crop yield being a quantitative character, it relies on many components. Therefore, the information on the association of yield and yield contributing characters is a prerequisite for crop improvement. It could be effectively implemented to formulate the criteria for selection strategies for improving the yield and quality parameters. But the correlation coefficient analysis does not provide the details related to the relative magnitude of involvement made by several yield components. Hence the concept of path coefficient analysis is practiced which helps partition the direct and indirect effects to measure the absolute status of all the characters and has practical implication in selection. The study of the association between set of characters and yield forms the basis for the future breeding programme. Keeping in view of the above facts, the present research has been carried out to study correlation and path analysis.

\section{MATERIAL AND METHODS}

The field experiment was carried out using twenty-six genotypes viz., Denkanikottai local, Kaveripattinam local, Mecheri local, PYR 15-01, Coll 29, HA 3, HA 4, CO 1, CO 2, Arka Vijay, Arka Swagath, Arka Joy, Arka Amogh, Arka sambhran, Thally local 2, Togarapuramrole local 1, Doddarayapet local 1, Somarpett local 1, Manuganahalli local 1, Agraharam thally local, Nagavalli local 1, Nagavalli local 2, Nallur local, Hulse local, Udhuru local and Bannekuppe local to study the correlation and path analysis. These genotypes were raised using Randomized Block Design with three replications at Regional Research Station, Paiyur, during Kharif 2020. The sowing was done with proper spacing of $90 \mathrm{~cm}$ and $90 \mathrm{~cm}$, row to row and plant to plant, respectively. Proper field management practices were carried out to establish a good crop. Observations were recorded on five randomly taken plants on days to fifty percent flowering, days to maturity, plant height, number of branches/plant, number of pod/plant, grain yield (g) and green pod yield (g). The correlation coefficient was calculated as per the method given by Al-Jibouri et al. (1958) and path coefficient analysis was estimated by the formula by Dewey and Liu (1959). The analysis was carried out using the software SPSS and TNAUSTAT.

\section{RESULTS AND DISCUSSION}

\section{Association studies}

The value of genotypic correlation coefficients was found relatively higher than the value of phenotypic correlation coefficients for all the traits indicating the regulation of phenotypic expression under the impact of environmental factors (Table 1).

Table 1. Correlation coefficients among seven biometrical characters assessed from 26 genotypes of Dolichos Bean (Lablab purpureus L.)

\begin{tabular}{|c|c|c|c|c|c|c|c|c|}
\hline Characters & & $\begin{array}{l}\text { Days to } 50 \% \\
\text { flowering }\end{array}$ & $\begin{array}{l}\text { Days to } \\
\text { maturity }\end{array}$ & $\begin{array}{c}\text { Plant } \\
\text { height }(\mathbf{c m})\end{array}$ & $\begin{array}{c}\text { Number of } \\
\text { branches/plant }\end{array}$ & $\begin{array}{l}\text { Number of } \\
\text { pod/plant }\end{array}$ & $\begin{array}{c}\text { Grain } \\
\text { yield (g) }\end{array}$ & $\begin{array}{l}\text { Green pod } \\
\text { yield (g) }\end{array}$ \\
\hline \multirow[t]{2}{*}{ Days to $50 \%$ flowering } & G & 1.000 & $1.000 * *$ & $0.470 *$ & $0.510 * *$ & 0.270 & 0.295 & 0.295 \\
\hline & $P$ & & $0.999 * *$ & $0.465 *$ & $0.472 * *$ & 0.268 & 0.289 & 0.292 \\
\hline \multirow[t]{2}{*}{ Days to maturity } & G & & 1.000 & $0.464 *$ & $0.504 * *$ & 0.264 & 0.289 & 0.289 \\
\hline & $\mathrm{P}$ & & & $0.460 *$ & $0.467 * *$ & 0.262 & 0.284 & 0.286 \\
\hline \multirow[t]{2}{*}{ Plant height } & G & & & 1.000 & $0.751 * *$ & $0.685 * *$ & $0.693 * *$ & $0.693 * *$ \\
\hline & $\mathrm{P}$ & & & & $0.703 * *$ & $0.678 * *$ & $0.670 * *$ & $0.675 * *$ \\
\hline \multirow[t]{2}{*}{ Number of branches/plant } & G & & & & 1.000 & $0.568 * *$ & $0.594 * *$ & $0.595 * *$ \\
\hline & $P$ & & & & & $0.533 * *$ & $0.549 * *$ & $0.550 * *$ \\
\hline \multirow[t]{2}{*}{ Number of pod/plant } & G & & & & & 1.000 & $0.991 * *$ & $0.991 * *$ \\
\hline & $P$ & & & & & & $0.971 * *$ & $0.981 * *$ \\
\hline \multirow[t]{2}{*}{ Grain yield (g) } & G & & & & & & 1.000 & $1.000 * *$ \\
\hline & $\mathrm{P}$ & & & & & & & $0.980 * *$ \\
\hline Green pod yield (g) & & & & & & & & 1.000 \\
\hline
\end{tabular}

* $\mathrm{P}<0.05 ; * * \mathrm{P}<0.01$ [G- Genotypic correlation coefficient, P- Phenotypic correlation coefficient] 
While variability studies deliver information on the degree of crop improvement through selection, they do not give detailed information on the extent and nature of association between the characters. They do not give detailed information on the extent and nature of the association between the characters that could be exploited for selection. The correlation studies in this study indicated higher estimates of genotypic correlation coefficients than their corresponding phenotypic correlation coefficients, suggesting a strong inherent relationship between various traits revealing that the environmental factors didn't influence the expression of the trait.

In the present study, number of pod/plant and grain yield (g) had highly significant and positive correlation with green pod yield and the green pod yield recorded moderately significant and positive association with plant height and number of branches/plant at both phenotypic and genotypic levels. The results were in line with the findings of Kujur et al. (2017). Green pod yield recorded non-significant positive correlation with days to fifty percent flowering and days to maturity. Singh et al. (2015) studied twenty-four Dolichos bean genotypes and observed that pod length, number of seeds per pod and number of pod per plant had significant positive association with pod yield per plant. Similar result of significant and positive association of green pod yield with number of branches per plant was reported by Chaudari et al. (2013) and Islam et al. (2011) reported that the number of pods per plant exhibited significant positive correlation with green pod yield.

Grain yield recorded highly significant and positive correlation with number of pods per plant which indicated that plant with more number of pods results in higher grain yield. Moderately significant and positive relationship was observed for grain yield with plant height and number of branches/ plant. Similar results were observed in the findings of Ravinaik et al. (2014). Grain yield recorded nonsignificant positive correlation with days to fifty percent flowering and days to maturity.

Table 2. Path coefficient analysis (on genotypic values) showing direct effect and indirect effects of seven characters on green pod yield in Dolichos Bean (Lablab purpureus L.)

\begin{tabular}{|c|c|c|c|c|c|c|c|}
\hline 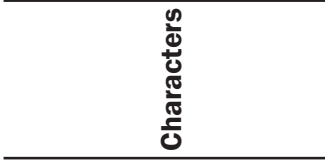 & 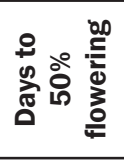 & 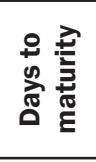 & 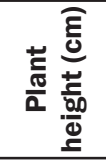 & 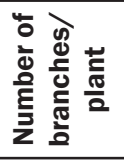 & 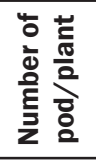 & 들 이 & $\begin{array}{l}\text { 을 } \\
\frac{0}{\Phi} \\
\frac{5}{0}\end{array}$ \\
\hline Days to $50 \%$ flowering & -3.976 & 3.986 & -0.015 & 0.076 & 0.608 & -0.382 & 0.297 \\
\hline Days to maturity & -3.975 & 3.986 & -0.015 & 0.075 & 0.594 & -0.375 & 0.291 \\
\hline Plant height & -1.876 & 1.858 & -0.031 & 0.111 & 1.544 & -0.904 & 0.702 \\
\hline Number of branches/plant & -2.116 & 2.097 & -0.025 & 0.143 & 1.319 & -0.796 & 0.623 \\
\hline Number of pod/plant & -1.078 & 1.057 & -0.022 & 0.084 & 2.241 & -1.285 & 0.997 \\
\hline Grain yield (g) & -1.185 & 1.165 & -0.022 & 0.089 & 2.246 & -1.282 & 1.011 \\
\hline
\end{tabular}

Note: Bold and diagonal figures indicate direct effect; Residual effect: 0.1234

Moderate significance and positive association were observed for number of pod/plant with plant height and number of branches/plant. The number of pod/plant recorded non-significant positive correlation with days to fifty percent flowering and days to maturity. Das et al. (2015) noted that the number of pods per plant displayed significant positive correlation with pod yield at both genotypic and phenotypic levels for pole-type Dolichos bean.

Number of branches/plant showed moderate significant positive correlation with days to fifty percent flowering, days to maturity and plant height. Plant height recorded a moderate significant positive relationship with days to fifty percent flowering and days to maturity at $5 \%$ level of probability at genotypic and phenotypic levels. Days to maturity recorded a perfect significant positive relationship with days to fifty percent flowering. Hence, plants that are early to flower are early to mature. Similar results were observed in the findings of Patel et al. (2014) for number of seeds/pod and days to last green pod harvest. No negative correlation was observed in the present study, which shows no negative relationship between the different characters studied.

From the above discussion, it is concluded that the green pod yield recorded moderate to higher significance along with positive association for plant height, number of branches/plants, number of pod/plant and grain yield at both phenotypic and genotypic levels, indicating that these traits may be considered as very important in selection because any improvement in these four characters would contribute to enhancement in green pod yield. Days to 50 percent flowering and days to maturity have shown perfect correlation and may be considered to develop early duration varieties. It is also suggested that hybridization of genotypes possessing combination of such characters will be helpful in finding desirable segregants.

\section{Path analysis}

Information about yield attributes can be obtained through correlation analysis but clear 
picture of comparative significance of direct as well as indirect effects of the allied characters towards yield can't be attained through correlation analysis. Hence, the detailed information of interrelationship between the characters and how the yield features impart their influence on yield and the traits that depend on grain yield, directly and indirectly, can be precisely determined with the help of path analysis.

The results of path analysis is shown in Table 2. Data revealed that days to fifty percent flowering (-3.976) directly negatively affected green pod yield. The results of the analysis were similar to the findings of Upadhyay and Mehta (2010). Strong positive indirect effects of days to fifty percent flowering on green pod yield were exhibited via days to maturity, number of branches/plant and number of pod/ plant. Concerning days to maturity, it recorded the first significant strong positive direct effect (3.986) on green pod yield, and it controlled the green pod yield positively through indirect effects via number of branches/plant and number of pod/plant.

Negative direct effect was observed for plant height on green pod yield but it influenced positively to green pod yield over its indirect effects via days to maturity, number of branches/plant and number of pod/plant. Number of branches/plant showed the positive direct effect on green pod yield (0.143). This trait had positive and indirect effects of days to maturity and number of pod/plant. Number of pod/plant indicated the $2^{\text {nd }}$ highest significant and positive direct effect on green pod yield (2.241) and its association with seed yield was positive at genotypic as well as phenotypic levels. The findings were in line with the results of Kiran et al. (2014). It inclined positively to green pod yield through its indirect effects via days to maturity and number of branches/plant. Singh et al. (2015) reported that traits days to fifty percent flowering, pod width, number of pods per plant and pod yield per plant have maximum direct effect.

Grain yield had negative direct effect on green pod yield. Positive contribution was noticed to green pod yield through its indirect effects via days to maturity, number of branches/plant and number of pod/plant.

\section{CONCLUSION}

Results of the association studies indicated that the number of pod/plant and grain yields had a predominant effect on green pod yield at both phenotypic and genotypic levels. Hence, there is ample scope in the improvement of green pod yield by selecting a genotype having higher number of pod/plant and grain yield since they are highly correlated.

Path coefficient studies indicated that the characters viz., days to maturity, number of $107 \mid 10-12$ | 4 branches/plant, number of pod/plant and green pod yield were the most valuable yield contributing components. They contributed to grain yield and green pod yield directly in positive direction. These four characters were considered as primary yield contributing components in field beans. Hence, the selection of these characters would show good effect on grain yield and green pod yield.

\section{Ethics statement}

No specific permits were required for the described field studies because no human or animal subjects were involved in this research.

\section{Originality and plagiarism}

We assure that we have written and submitted only entirely original works.

\section{Consent for publication}

All the authors are agreed to publish this research article.

\section{Competing interests}

There were no conflict of interest in the publication of this content

\section{Data availability}

All the data of this manuscript are included in the MS. No separate external data source is required. If anything is required from the MS, certainly, this will be extended by communicating with the corresponding author through corresponding official mail: geethakreddy@yahoo.com

\section{REFERENCES}

Al-Jibouri, H. A., Miller, P. A. and H. F. Robinson. 1958. Genotypic and environmental variances and covariances in an upland Cotton cross of interspecific origin 1. Agron J., 50(10): 633-636.

Chaudhari, P. P., Patel, A. I., Kadam, Y. R. and J. M. Patel. 2013. Variability, correlation and path analysis study in vegetable Indian bean [Lablab purpureus (L.) Sweet]. Crop Research., 45(1to3): 229-236.

Dewey, D. R. and Lu, K. 1959. A Correlation and PathCoefficient Analysis of Components of Crested Wheatgrass Seed Production 1. Agron J., 51(9): 515-518.

Das, I., Shende, V. D., Seth, T., Yadav, Y. and A. Chattopadhyay. 2015. Genetic analysis and interrelationships among yield attributing traits in pole and bush type dolichos bean (Lablab purpureus L.). J. Crop Weed.,11(2): 72-77.

Hoffman, R. 1995. Potent inhibition of breast cancer cell lines by the isoflavonoid kievitone: comparison with genistein. Biochem. Biophys. Res. Commun., 211(2): 600-606.

Islam, M. S., Rahman, M. M. and M. A. K. Mian. 2011. Genetic variability, heritability and correlation study in hyacinth bean. Bangladesh J Agr Res., 36(2): 351-356. 
Kiran, T. M., Lavanya, G. R. and G. S. Babu. 2014. Association analysis for pod yield and component characters in dolichos bean (Lablab purpureus L.). Electron. J. Plant Breed., 5(4): 820-823.

Kujur, P. K. and B. Vijay. 2017. Correlation and path analysis study in dolichos bean (Lablab purpureus L.). Trends in Biosciences., 10(29): 6151-6156.

Magalingam, V., Yassin, M. and Kumar, R. 2013. Genetic variability and character association in dolichos bean. SAARC J. Agric., 11(2): 161-171.

Patel, K. L., Sharma, G. L. and N. Mehta. 2014. Genetic Divergence analysis in Dolichos Bean (Dolichos Lablab L.). J. Plant Dev. Vol., 6(2): 315-318.
Ravinaik, K., Hanchinamani, C.N., Patil, M. G. and S. J. Imamsaheb. 2014. Correlation and path coefficient analysis in dolichos bean (Dolichos lablab L.) genotypes. Asian J. Hort., 9(2): 396-399.

Singh, B., Goswami, A. and D. K. Srivastava. 2014. Study of genetic variability, heritability and genetic advance in Table Pea (Pisum sativum (L.) spp. Hortense L.). Progressive Agriculture., 14(2): 280-284.

Upadhyay, D. and N. Mehta. 2010. Biometrical studies in dolichos bean (Dolichos lablab L.) for Chattisgarh plains. Res. J. Agril. Sci., 1(4): 441-447. 